\title{
The Influence of Education on The Depressing of Unemployment and The Increasing of The Society Economy in East Java
}

\author{
Suyanto', Bambang Purnomo $^{2}$, Rahmawati Erma Standsyah ${ }^{3}$ \\ \{suyanto_fe@unitomo.ac.id ${ }^{1}$, bambang.purnomo@unitomo.ac.id ${ }^{2}$, rahmawati.erma@unitomo.ac.id ${ }^{3}$ \} \\ ${ }^{1}$ Faculty Of Economics and Business Universitas Dr. Soetomo Surabaya, Indonesia \\ ${ }^{2}$ Faculty Of Teacher Education And Educational Sciences Universitas Dr. Soetomo Surabaya, \\ Indonesia \\ ${ }^{3}$ Faculty Of Teacher Education And Educational Sciences Universitas Dr. Soetomo Surabaya, \\ Indonesia
}

\begin{abstract}
High and sustainable economic improvement is the main requirement for continued economic development and prosperity. According to the BPS data, the province of Java is showing that the population of the province of Java is increasing year by year. The increase in the population also increases the unemployment rate. Therefore seek to reduce unemployment by improving the quality of education. The purpose of this study is to analyze the educational factors of the economy of society, directly and indirectly, through the unemployment rate in East Java in 2017. According to the results of the analysis, education has a direct and significant effect on improving the economy of society. the inhabitants of East Java with a coefficient increased by $67.6 \%$. The improvement of education can be achieved by increasing the School Participation Rate, Literacy rate and Highest level of education, so that its economy is based on the GRDP rate and the implicit GDP index also increase. But education has no significant effect on the economy of society indirectly through unemployment, as unemployment has no significant effect on the economy of the society.
\end{abstract}

Keywords: Education, unemployment, economy, East Java, SEM PLS.

\section{Introduction}

Development is an effort or process to create better change. The development process includes various social, political, economic and cultural aspects. Therefore, development is an absolute necessity for the survival of a country [1]. Economic development is a multidimensional process that involves major changes in social structure, public attitudes and national institutions, such as economic improvement, reduction of inequalities and decreasing of poverty.

High and sustainable economic improvement is the main requirement for continued economic development and prosperity. Because the population is growing every year, which in itself increases daily consumption needs, additional income is needed every year [2].

According to the BPS data, the province of Java is showing that the population of the province of Java is increasing year by year. From 2010, 37.565.706 people lived until 2017, 39.292.972 people [3], [4]. The increase was also followed by an increase in the new labor force, indicating that the increase in the population increased the labor force relative to 
employment, so that the number of unemployed rose to 840.000 [5]. It also affects the educational level of the East Java Society.

The gross enrollment rate for 2017 in basic education is still 7.23\% [6], and according to the results of the report on the prosperity of the people of East Java 2017, residents of East Java aged 15 who failed primary school was $21 \%$ and those who passed it $30 \%$. [7].

The economic improvement of a region is a measure of the prosperity of the region, while several factors can affect the growth of the economy. One of them is the unemployment rate. Based on the unemployment rate, we can see the situation of a country, whether the economy is developing or slowing down and even declining [2]. Similarly, the level of education of society is the dominant factor that must be given the highest priority to improve the quality of human resources

Much research has been conducted on the economy of society, including strategies to reduce poverty through local economic development in the era of decentralization [8], the effects of unemployment and poverty on the economy. economic growth of the province of Gorontalo [2], Influence of Unemployment, Economic Growth and Public Expenditure on District / City Human Development in Central Java Province in 2007-2011 [1], Analysis of the Influence of Public Expenditures in the Health Sector and the Sector of health on poverty in East Java [9], analysis of the effect of the human development index of the open unemployment rate and the minimum wage for the number of poor in Indonesia in 2011-2015 [10], analysis the influence of population, education and unemployment on poverty in East Java [11] and Some constraints to overcoming poverty in Indonesia [12].

Therefore, this study quantitatively examines, by SEM PLS analysis, the factors of economic influence of the East Java society based on educational variables through the unemployment rate as an intermediate variable. The purpose of this study is to analyze educational factors related to the economy of society, directly and indirectly, through the East Java unemployment rate.

\section{Methodology}

\subsection{Research Data Sources and Variables}

This research is a quantitative study using secondary data from the East Java BPS, resulting from the processing of data from the 2017 National Socio-Economic Survey (SUSENAS), the 2017 National Labor Force Survey and Projections for the East Java population. It was according to districts/cities up to 38 data.

The variables in this study are cross-sectional data. Referring to [1], [8], [13], the concept of constructing two latent variables and one manifest variable, as a whole, is as follows:

1. Educational Variables

- School Participation Rate Age Group 16-18 Years East Java 2017 (Percent)

- Literacy rate aged 10 years and over East Java 2017 (Percent)

- Highest level of education in East Java in 2017 (Percent)

2. Variable Open Unemployment Rate for 2017 East Java

3. Economic Variables

- ADHK GRDP without East Java Oil and Gas in 2017 Rate (Percent)

- Implicit ADHK GRDP without East Java Oil and Gas 2017 Rate (Percent) 


\subsection{Step Of Research}

In this study, data analysis on SEM-PLS will use SmartPLS software. The steps in analyzing the data to obtain interpretable model results are as follows:

1. Obtain a model based on concepts and theories to design structural models (relationships between latent variables used).

2. Design a measurement model, namely the relationship between indicator variables and latent variables. The design of a measurement model is performed by determining the type of indicator of each latent variable.

3. By creating a path diagram that explains the pattern of the relationship between the latent variables and the indicators, the conceptual model is obtained as follows.

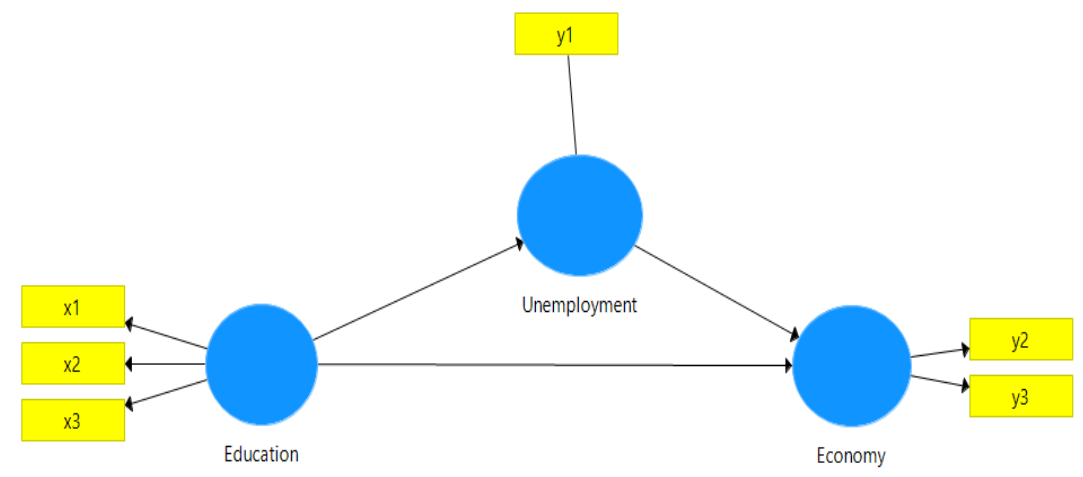

Fig. 1. Conceptual Research Model

4. Obtain models based on concepts and models for measurement models and structural models (the relationship between latent variables used).

Measurement Model :

- Educational Variables

$X_{1}=\lambda_{1} \xi_{1}+\delta_{1}$

$X_{2}=\lambda_{2} \xi_{1}+\delta_{2}$

$X_{3}=\lambda_{3} \xi_{1}+\delta_{3}$

- Economic Variables

$Y_{2}=\lambda_{4} \eta_{2}+\varepsilon_{1}$

$Y_{3}=\lambda_{5} \eta_{2}+\varepsilon_{2}$

structural Model :

- $\quad$ TPT Variables

$\eta_{1}=\gamma_{1} \xi_{1}+\zeta_{1}$

- Economic Variables

$\eta_{2}=\beta_{1} \eta_{1}+\gamma_{3} \xi_{1}+\zeta_{2}$

5. Evaluate the SEM-PLS model

6. Testing Hypotheses, Testing hypotheses consisting of:

a $\mathrm{H}_{0}$ : There is no direct influence of education on improving the economy of the Society

$\mathrm{H}_{1}$ : There is a direct influence of education on improving the economy of the Society

b $\quad \mathrm{H}_{0} \quad$ : There is no influence of education on improving the economy of society through the unemployment rate

$\mathrm{H}_{1} \quad$ : There is an influence of education on improving the economy of society through 
the unemployment rate

7. Interpretation of results and conclusions

\section{Results And Discussion}

\subsection{Descriptive Statistics}

Descriptive statistics are statistical techniques for displaying or describing data to be good information. Before analyzing the model of the influence between educational variables on economic variables and unemployment variables, descriptive variables were performed in the descriptive statistics of East Java to illustrate the characteristics of the data. The results of the descriptive statistics for the three variables of each indicator are as follows:

Table.1. Descriptive Statistics Results

\begin{tabular}{|c|c|c|c|c|c|c|}
\hline Definition & Variable & Mean & Med & Min & $\operatorname{Max}$ & StDev \\
\hline \multicolumn{7}{|l|}{ Educational } \\
\hline School Participation Rate Age & & & & & & \\
\hline $\begin{array}{l}\text { Group 16-18 Years East Java } \\
2017 \text { (Percent) }\end{array}$ & $X_{1}$ & 73.821 & 77.21 & 49.42 & 90.01 & 10.26 \\
\hline $\begin{array}{l}\text { Literacy rate aged } 10 \text { years and } \\
\text { over East Java } 2017 \text { (Percent) }\end{array}$ & $X_{2}$ & 95.532 & 93.5 & 80.75 & 98.84 & 4.83 \\
\hline $\begin{array}{l}\text { Highest level of education in } \\
\text { East Java in } 2017 \text { (Percent) }\end{array}$ & $X_{3}$ & 27.279 & 23.96 & 11.01 & 50.99 & 10.8 \\
\hline \multicolumn{7}{|l|}{ Unemployment Rate } \\
\hline $\begin{array}{l}\text { Open Unemployment Rate } \\
\text { (Percent) }\end{array}$ & $Y_{1}$ & 3.764 & 3.76 & 0.85 & 7.22 & 1.29 \\
\hline \multicolumn{7}{|l|}{ Economic } \\
\hline $\begin{array}{l}\text { ADHK GRDP without East } \\
\text { Java Oil and Gas in } 2017 \text { Rate } \\
\text { (Percent) }\end{array}$ & $Y_{2}$ & 5.353 & 5.26 & 4.46 & 6.56 & 0.43 \\
\hline $\begin{array}{l}\text { Implicit ADHK GRDP without } \\
\text { East Java Oil and Gas } 2017 \\
\text { Rate (Percent) }\end{array}$ & $Y_{3}$ & 2.921 & 2.92 & 1.82 & 4.39 & 0.46 \\
\hline
\end{tabular}

\subsection{Analysis of the Research Model}

The evaluation of the measurement model using loading factors is used to determine the validity of the indicators to form a latent variable, by examining the value of the reliability indicators and the convergent validity.

The reliability of the indicators shows which indicators of variance can be explained by latent variables. In the reliability indicator, a reflection indicator shall be removed from the measurement model when the absolute value of the load factor $(\lambda)$ is less than 0.4. The following is the result of the value of the loading factor $(\lambda)$ obtained. From Figure 2, all the indicators have a loading factor greater than 0.4 , which indicates that all the indicators explain the latent variables.

The convergent validity value shows the correlation value between the indicators that constitute a construct. The AVE value indicates the percentage of the average variance that can be explained by the building elements. AVE minimum value of 0.5 to indicate that the 
convergent size is of good validity. According to Figure 2, the AVE value of education and economy is greater than 0.5 , so that all the variables have convergent values of good validity.

The evaluation of the structural model in the SEM-PLS can be seen from the R-Square value $\left(R^{2}\right)$. Theoretically, it is explained that the value of $R^{2}$ is greater than 0.67 , that is the contribution of the exogenous variables to the strong endogenous, between 0.33 and 0.67 , with a sufficient or less contribution between 0.19 and 0.33 (Henseler, etc, 2009).

The results of data processing using SmartPLS obtained a value of $R^{2}$ for the education model of unemployment of $20.5 \%$, which means that education less contributes to unemployment in East Java, while the value of $R^{2}$ for the education model and the unemployment rate of the economy is $44.3 \%$. this value indicates that education and unemployment contribute sufficiently to the economy of the East Java Society

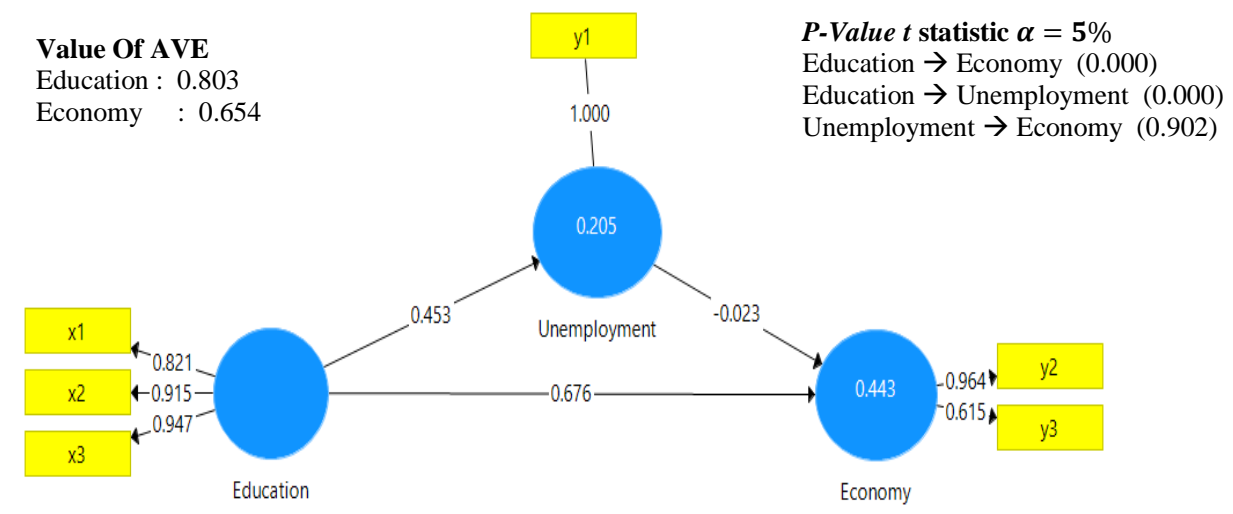

Fig. 2. Result Of Model

The measurement and the structural model after evaluation can then be continued by writing down the model in the equation. The equation obtained as a function of the latent variables of the model is as follows:

1. Measurement Model :

- $\quad$ Educational Variables

$$
\begin{aligned}
& X_{1}=0.821 \text { Education }+\delta_{1} \\
& X_{2}=0.915 \text { Education }+\delta_{2} \\
& X_{3}=0.947 \text { Education }+\delta_{3}
\end{aligned}
$$

- $\quad$ Economic Variables

$$
\begin{gathered}
Y_{2}=0.964 \text { Economy }+\varepsilon_{1} \\
Y_{3}=0.615 \text { Economy }+\varepsilon_{2}
\end{gathered}
$$

2. Structural Model :

- Open Unemployement Rate Variables

$$
\text { Unemployment }=0.453 \text { Education }+\zeta_{1}
$$

- Economic Variables

$$
\text { Economy }=-0.023 \mathrm{TPT}+0.676 \text { Education }+\zeta_{2}
$$




\section{Conclusions}

The results of the evaluation and measurement equations of the model and the structural model show that education has a direct and significant effect on the coefficient increase of 67.6\%. The improvement of education can be achieved by increasing the School Participation Rate, Literacy rate and Highest level of education so that the economy is at the same level as the GRDP rate and that the implicit GDP index also increases. But education has no significant effect on the economy of society indirectly through unemployment, as unemployment has no significant effect on the economy of the society. Education has a significant impact on unemployment with a coefficient of increase of $45.3 \%$. This increase is comparable to an increase in unemployment, which shows that in 2017, in East Java, there were many skilled unemployed. The current phenomenon is that many government programs are developed for vocational training activities.

\section{Acknowledgments}

The idea of this study is the idea of the author's originality and this research was supported by the Faculty Of Economics and Business and Faculty Of Teacher Education And Educational Sciences The University of Dr. Soetomo Surabaya.

\section{References}

[1] Nur Baeti, "Pengaruh Pengangguran, pertumbuhan ekonomi, dan pengeluaran pemerintah terhadap pembangunan manusia kabupaten/kota di provinsi jawa tengah," Econ. Dev. Anal. J., vol. 2, no. 3, p. 94, 2013.

[2] M. Arif Novriansyah, "Pengaruh Pengangguran dan Kemiskinan Terhadap Pertumbuhan Ekonomi di Provinsi Gorontalo," Gorontalo Dev. Rev., vol. 1, no. 1, p. 59, 2018.

[3] BPS Jawa Timur, Indikator Kesejahteraan Rakyat Provinsi Jawa Timur 2017. Surabaya: BPS Provinsi Jawa Timur, 2017.

[4] BPS Jawa Timur, Provinsi Jawa Timur Dalam Angka 2010. Surabaya: BPS Provinsi Jawa Timur, 2010.

[5] BPS Jawa Timur, Statistik Pemuda Provinsi Jawa Timur 2017. Surabaya: BPS Provinsi Jawa Timur, 2017.

[6] BPS Jawa Timur, "Laporan Eksekutif Pendidikan Provinsi Jawa Timur 2017," 2017.

[7] Z. Effendi, "Jenjang Pendidikan di Jatim Masih Rendah, Ini Kata Khofifah," detiknews. Jan-2019.

[8] S. Suyanto, "Strategi Memerangi Kemiskinan dengan Pengembangan Ekonomi Lokal pada Era Desentralisasi," J. EL-Ijtima, Media Komun. Pengemb. Masy. Madani, vol. 8, no. 1, pp. 21-38, Jan. 2007.

[9] N. Fithri and D. Kaluge, "Analisis Pengaruh Pengeluaran Pemerintah Sektor Pendidikan Dan Kesehatan Terhadap Kemiskinan Di Jawa Timur," J. Ekon. Pembang., vol. 15, no. 2, pp. 129-136, 2017.

[10] S. S. Ningrum, “Analisis Pengaruh Tingkat Pengangguran Terbuka, Indeks Pembangunan Manusia, Dan Upah Minimum Terhadap Jumlah Penduduk Miskin Di Indonesia Tahun 2011-2015,” J. Ekon. Pembang., vol. 15, no. 2, pp. 184-192, 2017.

[11] D. Mahsunah, "Analisis Pengaruh Jumlah Penduduk, Pendidikan Dan Pengangguran Terhadap Kemiskinan Di Jawa Timur,” J. Pendidik. Ekon., vol. 1, no. 3, pp. 1-17, 2013.

[12] S. Suyanto, "Beberapa Kendala dalam Menanggulangi Kemiskinan di Indonesia," $J$. Huk. Maksigama, vol. 10, no. 2, pp. 82-94, Nov. 2007.

[13] A. Jonnadi, S. Amar, and H. Aimon, “Analisis Pertumbuhan Ekonomi Dan Kemiskinan 
Di Indonesia," J. Kaji. Ekon., vol. 1, no. 1, 2012. 